\title{
O PROCESSO DE REVISÃO DE MANUSCRITOS E A MELHORIA DA QUALIDADE DAS PUBLICAÇÕES
}

\author{
Maria Helena Palucci Marziale ${ }^{1}$
}

Quando um manuscrito é apresentado a um periódico para publicação inicialmente o editor avalia se ele é de interesse e apropriado para ser publicado em seu periódico; posteriormente o encaminha para apreciação de conselheiros, onde então acontece o processo denominado "revisão por pares".

Na base de dados MEDLINE, o termo "revisão por pares" é definido como a avaliação realizada por especialistas da qualidade e pertinência de pesquisas ou de propostas de pesquisas de outros especialistas da mesma área ${ }^{(1)}$.

As principais publicações científicas, do mundo inteiro, utilizam a referida avaliação para apreciação de manuscritos submetidos à publicação. Embora muito discutida ultimamente em eventos científicos e em artigos divulgados em periódicos científicos e jornais, onde posições favoráveis e desfavoráveis são mencionadas, a revisão por pares parece estar distante de ser substituída.

Embora exista discordância em relação ao conceito de revisão por pares, e sobre como ela deve ser conduzida, parece existir concordância em relação ao que ela não é. Não é um processo científico completamente objetivo, pois a avaliação de qualidade de um manuscrito e de sua adequacidade para publicação em um periódico tem elementos subjetivos. Os revisores não tomam decisões definitivas, suas avaliações não determinam o destino de um manuscrito, mas sim auxiliam os editores a tomarem tais decisões.

0 processo de revisão por pares pode detectar os principais problemas em relação a originalidade e credibilidade científica do estudo, omissões importantes, rigor dos argumentos e os problemas no estilo de redação contribuindo, assim, para tornar a versão final do manuscrito mais sólida e facilitar sua leitura ${ }^{(2)}$.

Dentre as limitações do referido processo destaca-se: que ele não é capaz de assegurar a perfeição; determinar se os dados descritos são fidedignos; é responsável pelo aumento do período gasto para avaliação do manuscrito e subsequente atraso na publicação; pode estar sujeito a viéses e tornar-se oneroso, não é capaz de detectar com facilidade o conflito de interesses por parte de um ou mais autores do manuscrito e não assegura que publicações duplicadas serão descobertas ${ }^{(1)}$.

Apesar das limitações, a revisão por pares ocupa um papel central no processo de publicação de um periódico. Ela pode existir fundamentalmente para auxiliar na detecção e descrição das falhas e oferece aos pesquisadores renomados a oportunidade de reconhecerem, estimularem e apoiarem a pesquisa inovadora.

Enquanto editores consideramos que a revisão dos manuscritos realizadas pelos conselheiros tem contribuindo de forma significativa para a melhoria da qualidade dos artigos publicados neste periódico.

\section{REFERÊNCIAS BIBLIOGRÁFICAS}

1. Lynne MS, Jo LH. Manuscript peer review - a guide for health care professionals. Pharmacotherapy 2001; $21(4): 395-404$.

2. Lock S. Does editorial peer review work? Am Inter Med 1994; 121(1): 60-1.

\footnotetext{
${ }^{1}$ Presidenta da Comissão de Editoração da Revista Latino-Americana de Enfermagem e Professor Livre-Docente da Escola de Enfermagem de Ribeirão Preto da Universidade de São Paulo, Centro Colaborador da OMS para o desenvolvimento da pesquisa em enfermagem, e-mail: marziale@eerp.usp.br
} 


\title{
THE PROCESS OF MANUSCRIPT REVIEW AND THE IMPROVEMENT IN PUBLICATION QUALITY
}

\author{
Maria Helena Palucci Marziale ${ }^{1}$
}

When a manuscript is submitted to a journal for publication, the editor firstly evaluates if it is appropriate to be published in that specific journal. The manuscript is then sent to reviewers, which is when the so-called "peer review" process takes place.

In MEDLINE, the term "peer review" is defined as the assessment made by specialists of the quality and relevance of research or research proposals by other specialists working in the same field ${ }^{(1)}$.

The major scientific publications worldwide use that type of evaluation in order to assess manuscripts submitted for publication. Although a lot of discussion has taken place lately in conferences as well as in articles published in scientific journals in which favorable and unfavorable opinions are presented, peer review seems to be far from being replaced.

Although a great deal of disagreement exists concerning the concept of peer review and how it should be conducted, there seems to be an agreement in relation to what it is not. It is not a completely objective scientific process, since the assessment of a manuscript's quality and of its adequacy for publication in a journal has subjective elements. Reviewers do not make definitive decisions, their evaluations do not determine the fate of manuscript, but help editors to make decisions.

The peer-review process can detect the main problems concerning the originality and scientific credibility of a study as well as important omissions, accuracy of arguments and problems concerning writing style, thus contributing to making the final version of the manuscript more solid and facilitating its reading ${ }^{(2)}$.

Among the limitations of such process, its is emphasized that; it is not capable of ensuring perfection or determining if the described data are reliable; its is responsible for increasing the time necessary for manuscript evaluation and its subsequent delay in publication; it may be subject to bias and become costly; it is not capable of easily detecting the conflict of interests on the part of one or more authors and does not ensure that duplicate publications will be discovered ${ }^{(1)}$.

In spite of its limitations, peer review plays a central role in a journal's publication process. It fundamentally exists in order to help in the detection and description of flaws and offers renowned researchers the opportunity to recognize, stimulate and support innovative research.

As editors, we consider that the peer review of manuscripts has significantly contributed to improve the quality of the articles published in this journal.

\section{REFERENCES}

1. Lynne MS, Jo LH. Manuscript peer review - a guide for health care professionals. Pharmacotherapy $2001 ; 21$ (4): 395-404.

2. Lock S. Does editorial peer review work? Am Inter Med 1994; 121(1): 60-1.

\footnotetext{
${ }^{1}$ President of the Publishing Committee of Revista Latino-Americana de Enfermagem and Associate Professor at the University of São Paulo at Ribeirão Preto College of Nursing, WHO Collaborating Center for Nursing Research Development, e-mail: marziale@eerp.usp.br
} 


\title{
EL PROCESO DE REVISIÓN DE MANUSCRITOS Y LA MEJORÍA DE LA CUALIDAD DE LAS PUBLICACIONES
}

\author{
Maria Helena Palucci Marziale ${ }^{1}$
}

Cuando un manuscrito es presentado a una revista para publicación inicialmente el editor evalúa si él es de interés y apropiado para ser publicado en su revista; posteriormente el editor lo envía para apreciación de consejeros, en donde sucede entonces el proceso denominado "revisión por pares".

En la base de datos del MEDLINE, el término "revisión por pares" es definido como la evaluación realizada por especialistas de calidad y pertinencia de investigaciones o de propuestas de investigaciones de otros especialistas de la misma área ${ }^{(1)}$.

Las principales publicaciones científicas del mundo entero, utilizan la referida evaluación para apreciación de manuscritos sometidos a publicación. Aunque ha sido muy discutida últimamente en eventos científicos y en artículos divulgados en revistas científicas en las cuales posiciones favorables y desfavorables son mencionadas, la revisión por pares parece estar lejos de ser substituida.

A pesar de que existe discordancia en relación con el concepto de revisión por pares y sobre cómo ésta debe ser conducida, parece existir acuerdo en relación con lo que ella no es. No es un proceso científico completamente objetivo, pues la evaluación de la calidad de un manuscrito y su adecuación para publicación en una revista tiene elementos subjetivos. Los revisores no toman decisiones definitivas, sus evaluaciones no determinan el destino de un manuscrito, pero si ayudan a los editores a tomar tales decisiones.

El proceso de revisión por pares puede detectar los principales problemas en relación con la originalidad y credibilidad científica del estudio, omisiones importantes, rigor de los argumentos y los problemas en el estilo de redacción, contribuyendo así, para tornar la versión final del manuscrito en una versión más sólida y facilitar su lectura ${ }^{(2)}$.

Dentro de las limitaciones del referido proceso se destacan: Él no es capaz de asegurar la perfección; determinar si los datos si los datos descritos son fidedignos; es responsable por el aumento del tiempo gastado para la evaluación del manuscrito y por consiguiente del atraso en la publicación; puede estar sujeto a errores y tornarse oneroso, no es capaz de detectar con facilidad el conflicto de intereses por parte de uno o más autores del manuscrito y no asegura que publicaciones duplicadas sean descubiertas ${ }^{(1)}$.

A pesar de las limitaciones, la revisión por pares ocupa un papel central en el proceso de publicación de un periódico. Ella puede existir fundamentalmente para ayudar en la detección y descripción de las fallas y ofrece a los investigadores renombrados la oportunidad de reconocer, estimular y apoyar la investigación innovadora.

Como investigadores consideramos que la revisión de los manuscritos realizadas por los consejeros han contribuido de forma significativa para la mejoría de la calidad de los artículos publicados en éste periódico.

\section{REFERENCIAS BIBLIOGRÁFICAS}

1. Lynne MS, Jo LH. Manuscript peer review - a guide for health care professionals. Pharmacotherapy 2001; 21(4): 395-404.

2. Lock S. Does editorial peer review work? Am Inter Med 1994; 121(1): 60-1

\footnotetext{
${ }^{1}$ Presidenta de la Comisión Editorial de la Revista Latinoamericana de Enfermería y Profesor Libre-Docente de la Escuela de Enfermería de Ribeirão Preto de la Universidad de São Paulo, Centro Colaborador de la OMS para el desarrollo de la Investigación en Enfermería, e-mail: marziale@eerp.usp.br
} 
